\title{
Ultrastructural detection of granulated cells in the autonomic ganglia of the rat pancreas
}

\author{
D. Baetens ${ }^{1}$, M. Vasko ${ }^{2}$, R.H. Unger ${ }^{2}$ and L. Orci ${ }^{1}$ \\ ${ }^{1}$ Institute of Histology and Embryology University of Geneva Medical Center, Geneva, Switzerland \\ ${ }^{2}$ Veterans Administration Medical Center and University of Texas Health Science Center, Dallas, Texas, USA
}

\begin{abstract}
Summary. Electron microscopic examination of the intrinsic autonomic ganglia of the rat pancreas revealed the presence of small cells, when compared to the principal ganglionic neurons, within a particular type of ganglia. The small cells were often located in clusters around fenestrated capillaries, but their most striking characteristic was the presence of catecholamine-like granules distributed throughout the cytoplasm. The possible implication of this new source of catechol-
\end{abstract}

amines, acting either as interneurons or as neuroendocrine cells, is discussed in the light of a local regulatory mechanism for islet secretion.

Key words: Autonomic nervous system, intrinsic ganglia, small granulated cells, catecholamines, islets of Langerhans, electron microscopy.
Certain of the physiologic responses of the endocrine pancreas are mediated by sympathetic discharge via direct stimulation from the central nervous system [1, 2]. However, we have recently observed that the glucagon response to glucopenia in the isolated perfused rat pancreas can be largely blocked by phentolamine [3]. Although we concluded that this alpha-adrenergically mediated response to glucopenia must reflect norepinephrine release from severed perinsular sympathetic nerve endings independent of the central nervous system, and since there is no other known source of catecholamines in the pancreas, we undertook a search for an alternative source of catecholamines. In this report we present ultrastructural evidence for a second source of catecholamines based on the demonstration of small cells containing catecholamine-like granules within the intrinsic autonomic ganglia of the rat pancreas.

\section{Materials and methods}

Three normal albino rats (SiVZ strain, body weight $110-160 \mathrm{~g}$ ) were used in this study. Under ether anaesthesia the animals were perfused through the left ventricle with $1 \%$ glutaraldehyde and $1 \%$ paraformaldehyde in $0.1 \mathrm{~mol} / 1$ phosphate buffer $(\mathrm{pH} \mathrm{7.4)}$ after rinsing of the circulation with $0.9 \% \mathrm{NaCl}$ solution. After fixation, small samples of both ventral and dorsal parts of the pancreas were dissected out, postfixed in $2 \%$ buffered $\mathrm{OsO}_{4}$, dehydrated and embedded in Epon. Pancreatic ganglia were identified on $1 \mu \mathrm{m}$ thick toluidine blue stained sections. After staining with uranyl acetate and lead citrate, ultrathin sections were viewed in a Philips EM 301 electron microscope. For the quantitative analysis, the volume density of the different compo- nents of 8 ganglia (principal neurons, small granulated cells, satellite cells and blood capillaries) was determined on semithin sections using the point-counting method [4]. Data for each component were expressed as $\%$ of the total volume density occupied by the 8 ganglia. In the small granulated cells, the size $(\mathrm{nm})$ and density (number $\left./ \mu \mathrm{m}^{2}\right)$ of the vesicles was quantified on electron micrographs at 55000 magnification, calibrated with a Fullham reference grid, 2160 lines $/ \mathrm{mm}$ (Schenectady, NY, USA).

\section{Results}

In both duodenal and splenic parts of the pancreas (Fig. 1), two types of autonomic ganglia were observed. One was of relatively small size (mean diameter $42.3 \pm$ $3.7 \mu$ ), and composed chiefly of ganglionic neurons. The second was much larger (mean diameter $83.7 \pm 6.1 \mu$ ), and contained ganglion cells, numerous capillaries and a population of granulated cells of smaller size than the principal ganglionic neurons (Fig. 2). In 8 such ganglia examined, $36.6 \%$ of the volume density was occupied by principal neurons, $14.9 \%$ by small granulated cells, $17.7 \%$ by blood capillaries, $9.1 \%$ by satellite cells and the remainder by neuronal processes and connective tissue. The granulated cells were found in clusters around the blood vessels, in the peripheral areas of the ganglion, or as solitary cells in the vicinity of the ganglion cells. Certain clusters were surrounded by a connective tissue capsule. Individual or clustered granulated cells were usually covered by glial processes of satellite cells which separated them from the intercellular space and 


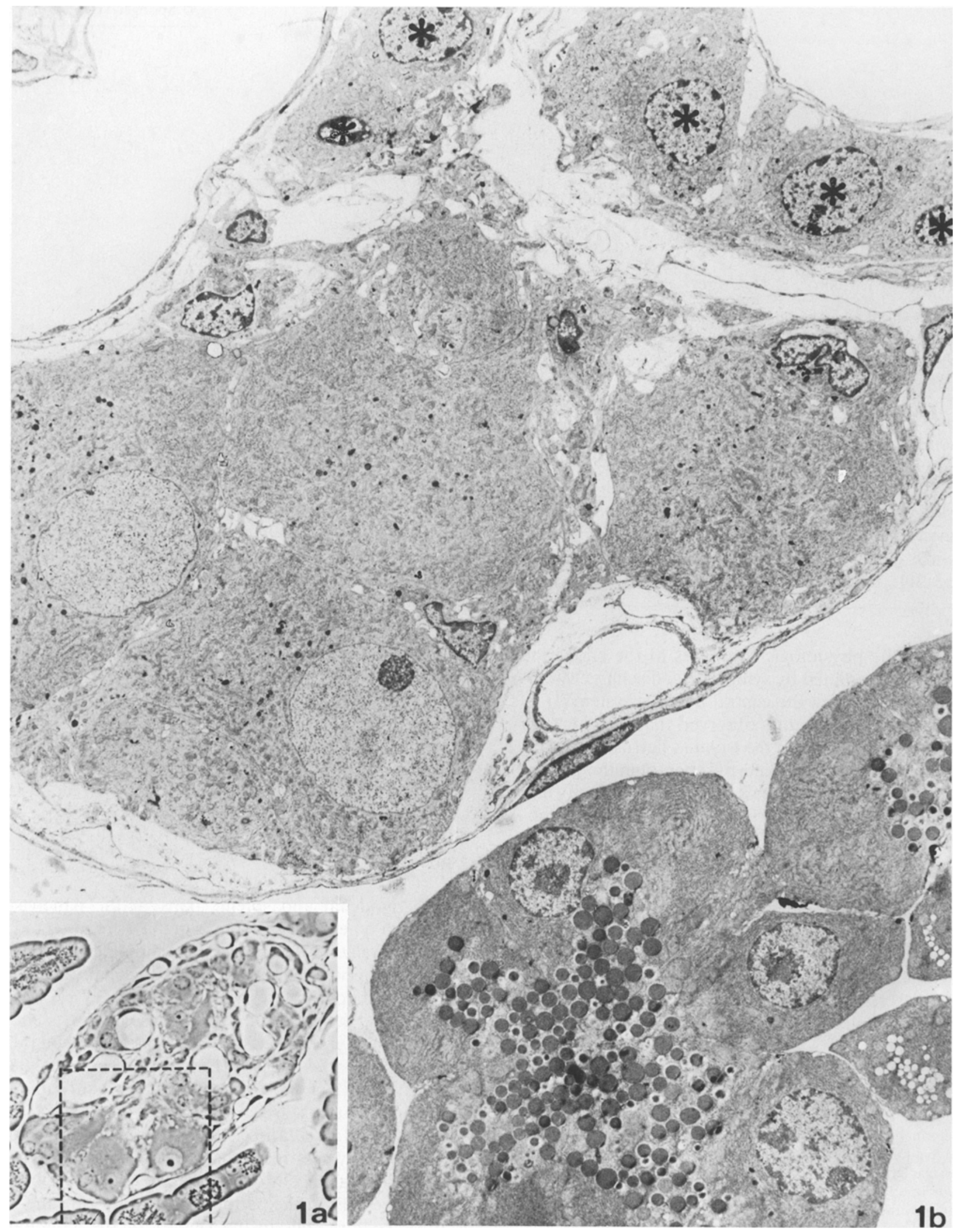

Fig. 1. a Semithin section of an intrinsic autonomic ganglion in the duodenal part of the rat pancreas. $\times 400 \mathrm{~b}$ Higher magnification of the area outlined in a on a consecutive ultrathin section showing principal ganglion cells with a large pale nucleus and small granulated cells (asterisks), clustered around blood capillaries and characterised by their chromatin-dense nucleus. In the lower right corner the cells with large granules neighbouring the autonomic ganglion are zymogen-containing acinar cells of the exocrine pancreas. $\times 3400$ 


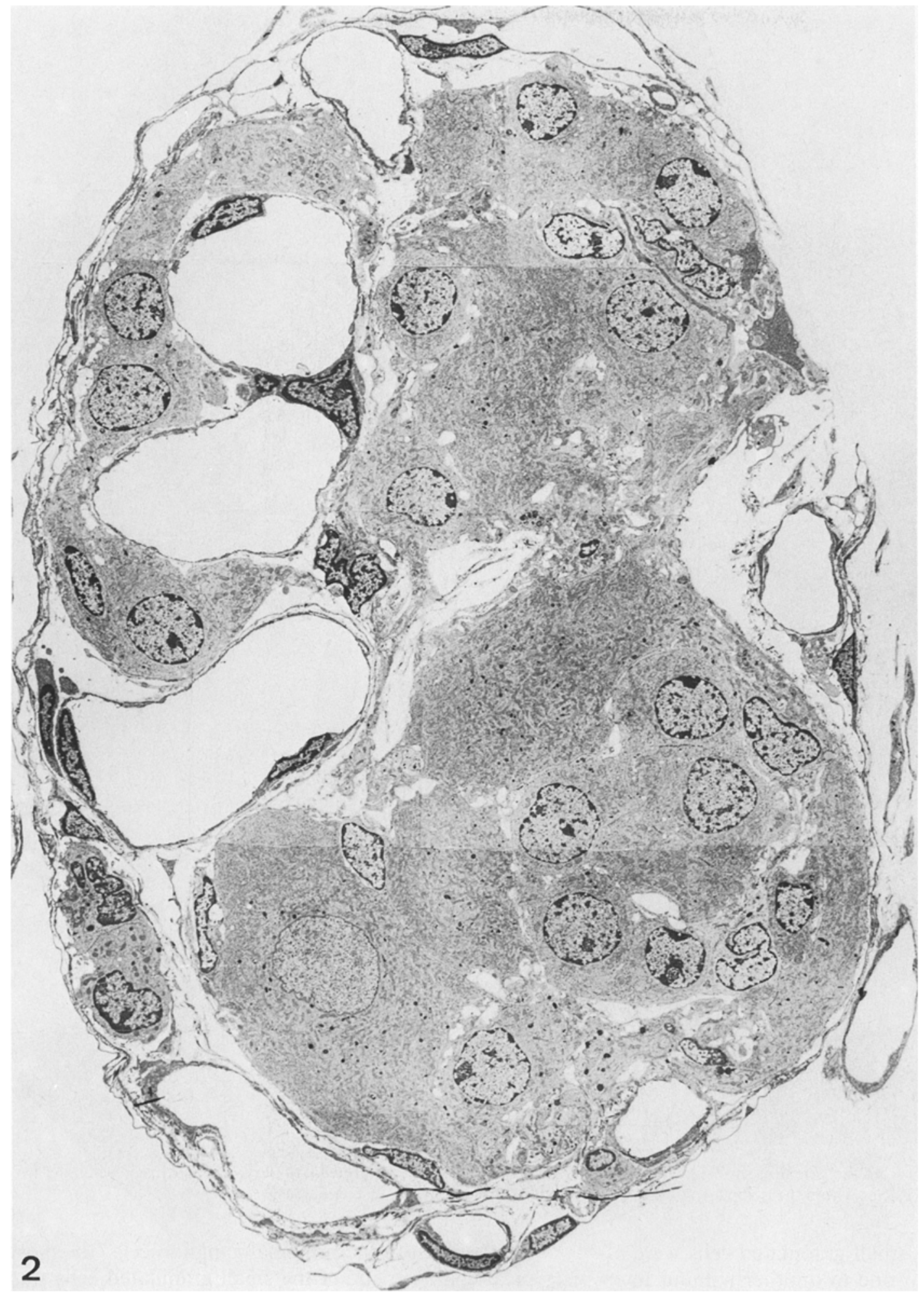

Fig. 2. Reconstruction of an autonomic ganglion of the rat pancreas with numerous capillaries and a population of small granulated cells outnumbering the principal ganglionic neurons. Irregularly shaped nuclei belong to glial cells

the surrounding ganglion cells. These glial sheets, however, were not continuous; at various locations, especially near the blood vessels, the cell membrane of the granulated cells was separated from the interstitial tissue by only a basal membrane. Capillaries in the prox- imity of the small granulated cells showed a peculiar feature, i.e., their endothelium was fenestrated as in endocrine glands (Fig. 3), whereas the capillaries around the principal ganglion cells showed a continuous endothelium. 


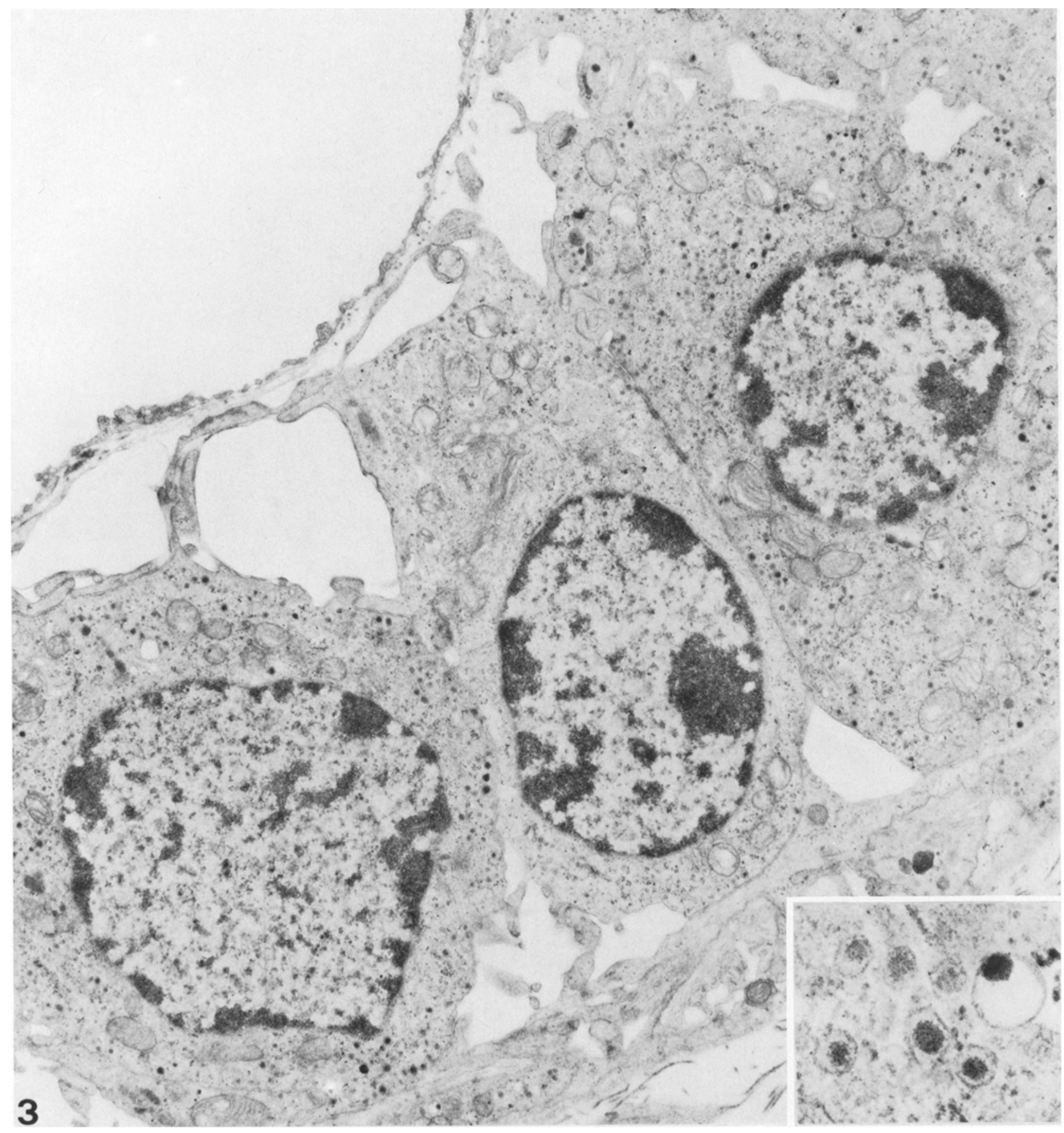

Fig. 3. Small granulated cells from the ganglion shown in Figure 1, in close apposition to a fenestrated capillary. The inset represents the two types of granule-containing vesicles within the cytoplasm of the small granulated cells. $\times 14300$, inset $\times 62400$

Within the clusters, small granulated cells were often in direct apposition one to another without interposed glial processes. Membrane specializations characteristic of intermediate junctions were seen in these areas. At some sites the intercellular space separating neighboring small granulated cells was widened and occupied by cytoplasmic digitations of the cells, by neuronal or glial processes or by collagen fibers. Although lacking typical dendrites and axons, small granular cells showed cytoplasmic processes in continuity with the cell body and bore granular vesicles (see below).
In contrast to the principal ganglion cells, the most typical characteristic of the small granulated cells was the presence of core-containing vesicles. These were distributed throughout the cytoplasm, but often concentrated just beneath the cell membrane. Within the same cell two morphologically distinct types of core-containing vesicles were found. The majority of the vesicles were of small size (105 to $130 \mathrm{~nm}$ ), round or slightly ovoid and contained a centrally located core of moderate electron density. The other vesicles were of larger size $(240$ to $270 \mathrm{~nm}$ ), equally round, but the granular 
core was highly osmiophilic and located eccentrically, often apposed to the limiting membrane (Fig.3). The latter vesicles were rare, representing only $2 \%$ of the total vesicle population within one cell (the number of such vesicles per square micrometer of cytoplasm was $0.10 \pm 0.01$ versus $5.3 \pm 0.5$ for the small sized vesicles). Cells containing only the large type vesicles as described in the sympathetic superior cervical ganglion [5, $6,7]$ were not observed.

\section{Discussion}

The intrinsic ganglia of the pancreas [8] were previously considered to be parasympathetic [9-11]. However, using the fluorescence histochemical technique of Falck and Hillarp [12], Alm et al. [13] reported the presence of catecholamine-containing small intensely fluorescent (SIF) cells in an intrapancreatic ganglion, composed otherwise of non-fluorescent ganglion cells. The ultrastructural aspect of the small granulated cells within the intrinsic autonomic ganglia of the rat pancreas, as reported in the present study, also suggests that they may contain catecholamines and correspond to the SIF-cells described by light microscopy [13]. Small type vesicles resembled those of the adrenaline-containing cells of the adrenal medulla with respect to the position and density of the central core, while the large-sized vesicles were similar to those of the adrenal noradrenaline-storing cells. However, in the pancreatic granulated cells, both types of vesicles were found within the same cell.

In the sympathetic ganglia (e.g. superior cervical ganglion) the observation of cytoplasmic processes carrying granular vesicles together with afferent and efferent synapses on small granulated cells has led several authors to postulate that these cells could act as interneurons regulating ganglionic transmission $[5,6,14-22]$. Moreover, the localization of some of the small granulated cells in clusters near fenestrated blood capillaries $[5,16,23]$, a feature characteristic of endocrine glands, has suggested an endocrine function for the small granulated cells $[5,6,16,19-21,24]$. Others believe that the disposition of the granulated cells close to blood capillaries favors the theory of a chemoreceptive function for these cells receiving stimuli from blood components $[6$, 25-27]. In the ganglia of the pancreas, the small granulated cells are also located near fenestrated capillaries and near principal neurons. The cellular processes of the pancreatic granulated cells are, however, relatively short, ending in the vicinity of the cell body or in the proximity of the ganglion cells without forming clear synaptic contacts. They were never seen to leave the ganglion even when consecutive serial sections of the same cell were examined. On the other hand, the granular vesicles were often concentrated in an area just beneath the plasma membrane suggesting a possible neuroendocrine secretion mechanism. However, no morphologic evidence for exocytosis of granules was found.
Dopamine is said to be present in the rat pancreatic ganglia [28]. It is therefore possible that small granulated cells in these ganglia store dopamine in addition to other catecholamines, acting as interneurons by altering the sensitivity of the principal neurons to acetylcholine released from preganglionic neurons [29, 30]. Alternatively, by secreting their monoamine content directly into the circulation they might modify the responses of peripheral structures such as pancreatic islets [30]. Dopamine, like other catecholamines, is known to inhibit glucose-induced insulin release from islets of ob/ob mice [31] and to stimulate glucagon secretion [32,33].

Moreover, immunocytochemical studies have revealed vasoactive intestinal polypeptide (VIP), substance $\mathrm{P}$, enkephalin, and $\mathrm{COOH}$-terminal gastrin/ cholecystokinin immunoreactivity in the pancreatic nerves [34], and for at least one of these peptides, VIP, immunoreactive ganglion cells were also found $[35,36]$. VIP [37, 38] and C-terminal cholecystokinin tetrapeptide [39] were reported to stimulate glucagon secretion.

These observations do not exclude the possibility that the small granulated cells in the rat pancreas contain both catecholamines and peptide neurotransmitters. Conceivably, a component of the alpha-adrenergically mediated response of glucagon to glucopenia observed in the isolated pancreas originates in these cells, although their relationship to islet cells is not yet known.

Acknowledgements. We thank Dr. A. Perrelet for reviewing the manuscript, Ms. E. Sutter, H.Chatelain and Mr. G. Negro for technical assistance and Ms. M. Muller for typing. This work was supported by the Swiss National Science Foundation grant 3.460 .83 , by the VA Institutional Research Support grant 549-8000-01 and by the National Institutes of Health grant AM-02700-25.

\section{References}

1. Woods S, Porte Jr D (1974) Neural control of the endocrine pancreas. Physiol Rev 54: 596-619

2. Miller RE (1981) Pancreatic neuroendocrinology: Peripheral neural mechanisms in the regulation of the islets of Langerhans. Endocrine Rev 2: 471-494

3. Hisatomi A, Maruyama H, Orci L, Vasko M, Unger RH (1985) Adrenergically mediated intrapancreatic control of the glucagon response to glucopenia in the isolated rat pancreas. J Clin Invest $75: 420-426$

4. Weibel ER (1973) Stereological techniques for electron microscopic morphometry. In: Hayat MA (ed.) Principles and techniques of electron microscopy. Biological applications, Vol 3. Van Nostrand Reingold, New York, pp 237-296

5. Siegrist G, Dolivo M, Dunant Y, Foroglou-Kerameus C, de Ribaupierre Fr, Rouiller Ch (1968) Ultrastructure and function of chromaffin cells in the superior cervical ganglion of the rat. J Ultrastr Res 25: 381-407

6. Lu K-S, Lever JD, Santer RM, Presley R (1976) Small granulated cell types in rat superior cervical and coeliac-mesenteric ganglia. Cell Tiss Res 172: 331-343

7. Abe H (1983) Ultrastructural study on the granule-containing cells in the rat autonomic ganglia. Tohoku J Exp Med 139: 399-409

8. Richins CA (1945) The innervation of the pancreas. J Comp Neurol 83: $223-236$ 
9. Honjin R (1956) The innervation of the pancreas of the mouse, with special reference to the structure of the peripheral extension of the vegetative nervous system. J Comp Neurol 104: 331-371

10. Coupland RE (1958) The innervation of pancreas of the rat, cat and rabbit as revealed by the cholinesterase technique. $J$ Anat (London) 92: 143-149

11. Legg PG (1968) Fluorescence studies on neural structures and endocrine cells in the pancreas of the cat. Z Zellforsch 88: 487-495

12. Falck B, Hillarp N-A, Thieme G, Torp A (1962) Fluorescence of catecholamines and related compounds condensed with formaldehyde. J Histochem Cytochem 10:348-354

13. Alm P, Cegrell L, Ehinger B, Falck B (1967) Remarkable adrenergic nerves in the exocrine pancreas. $Z$ Zellforsch 83: 178-186

14. Norberg KA, Sjögvist F (1966) New possibilities for adrenergic modulation of ganglionic transmission. Pharmacol Rev 18: 743-751

15. Williams TH (1967) Electron microscopic evidence for an autonomic interneuron. Nature (London) 214: 309-310

16. Matthews MR, Raisman G (1969) The ultrastructure and somatic efferent synapses of small granule-containing cells in the superior cervical ganglion. J Anat (London) 105: 255-282

17. Williams TH, Palay SL (1969) Ultrastructure of the small neurons in the superior cervical ganglion. Brain Res 15:17-34

18. Watanabe H (1971) Adrenergic nerve elements in the hypogastric ganglion of the guinea pig. Am J Anat 130:305-330

19. Williams TH, Chiba T, Black AC Jr, Bhalla RC, Jew JY (1976) Species variations in SIF cells of superior cervical ganglia: are there two functional types. In: Eränkö O (ed) SIF cells, structure and function of the small, intensely fluorescent sympathetic cells. Fogarty International Center Proceedings 30, US Government Printing Office, Washington DC, pp 143-162

20. Chiba T (1977) Monoamine-containing paraneurons in the sympathetic ganglia of mammals. Arch Histol Jap 40 (Suppl): $163-176$

21. Williams TH, Black AC Jr, Chiba T, Jew JY (1977) Species differences in mammalian SIF cells. In: Costa E, Gessa GL (eds) Nonstriatal dopaminergic neurons. Advances in biochemical psychopharmacology 16. Raven, New York, pp 505-511

22. Libet $B$ (1977) The role SIF cells play in ganglionic transmission. In: Costa E, Gessa GL (eds) Nonstriatal dopaminergic neurons. Advances in biochemical psychopharmacology 16. Raven, New York, pp 541-546

23. Abe H, Watanabe H, Yamamoto TY (1983) Relationship between granule-containing cells and blood vessels in the rat autonomic ganglia. Anat Rec 205: 65-72

24. Elfvin LG, Hökfelt T, Goldstein M (1975) Fluorescence microscopical, immunohistochemical and ultrastructural studies on sympathetic ganglia of the guinea pig, with special references to the SIF cells and their catecholamine content. J Ultrastruct Res 51: $377-396$

25. Eränkö O, Eränkö L (1971) Small, intensely fluorescent granulecontaining cells in the sympathetic ganglion of the rat. In: Eränkö $O$ (ed) Histochemistry of nervous transmission. Progress in brain research 34. Elsevier, Amsterdam, pp 39-51

26. Lever JD, Santer RM, Lu K-S, Presley R (1976) Chromaffin-positive and small intensely fluorescent cells in normal and amine- depleted sympathetic ganglia. In: Coupland RE, Fujita T (eds) Chromaffin, enterochromaffin and related cells. Elsevier, Amsterdam, pp 83-93

27. Matthews MR (1980) Ultrastructural studies relevant to the possi-

ble functions of small granule-containing cells in the rat superior cervical ganglion. Adv Biochem Psychopharmacol 25: 77-86

28. Björklund A, Cegrell L, Falck B, Ritzen M, Rosengren E (1970) Dopamine-containing cells in sympathetic ganglia. Acta Physiol Scand 78: $334-338$

29. Libet B, Tosaka T (1970) Dopamine as a synaptic transmitter and modulator in sympathetic ganglia; a different mode of synaptic action. Proc Natl Acad Sci USA 67: 667-673

30. Neff NH, Karoum F, Hadjiconstantinou M (1983) Dopaminecontaining small intensely fluorescent cells and sympathetic ganglion function. Fed Proc 42: 3009-3011

31. Lindstrom P (1982) Modification of mouse islet function by 5-hydroxytryptamine, dopamine and their precursors. Acta Biol Med Ger 41: 1185-1190

32. Le Blanc H, Lachelin GCL, Abu-Fadil S, Yen SSC (1977) The effect of dopamine infusion on insulin and glucagon secretion in man. J Clin Endocrinol Metab 44: 196-198

33. Lorenzi M, Karam JH, Tsalikian E, Bohannon NV, Gerich JE, Forsham PH (1979) Dopamine during $\alpha$ - or $\beta$-adrenergic blockade in man. J Clin Invest 63:310-317

34. Larsson L-I, Rehfeld JF (1979) Peptidergic and adrenergic innervation of pancreatic ganglia. Scand J Gastroenterol 14: 433-437

35. Sundler F, Alumets J, Håkanson R, Fahrenkrug J, Schaffalitzky de Muckadell O (1978) Peptidergic (VIP) nerves in the pancreas. Histochem 55:173-176

36. Bishop AE, Polak JM, Green IC, Bryant MG, Bloom SR (1980) Location of VIP in the pancreas of man and rat. Diabetologia 18: $73-78$

37. Schebalin M, Said SI, Makhlouf GM (1977) Stimulation of insulin and glucagon secretion by vasoactive intestinal peptide. Am J Physiol 232: E197-E200

38. Szecowka J, Sandberg E, Efendic S (1980) The interaction of vasoactive intestinal polypeptide (VIP), glucose and arginine on the secretion of insulin, glucagon and somatostatin in the perfused rat pancreas. Diabetologia 19:137-142

39. Rehfeld JF, Larsson LI, Goltermann NR, Schwartz TW, Holst JJ, Jensen SL, Morley JS (1980) Neural regulation of pancreatic hormone secretion by the C-terminal tetrapeptide of CCK. Nature (London) 284: 33-38

Received: 7 June 1985

and in revised form: 27 September 1985

Dr. D. Baetens

Institute of Histology and Embryology

University of Geneva CMU

1 , rue Michel Servet

CH-1211 Geneva 4

Switzerland 